\title{
The Effects of External Factors on Perceived Ease of Use, Perceived Usefulness, Attitude Towards Use, and Behav- ioral Intention of Older Adults in Indonesia
}

\author{
Levina Nathania ${ }^{1}$ Indarini $^{2 *}, \&$ Dudi Anandya ${ }^{3}$ \\ ${ }^{1}$ University of Surabaya, Surabaya, Indonesia \\ ${ }^{2}$ University of Surabaya, Surabaya, Indonesia \\ ${ }^{3}$ University of Surabaya, Surabaya, Indonesia \\ ${ }^{*}$ Corresponding author. Email: inda@staff.ubaya.ac.id
}

\begin{abstract}
The purpose of this research is to analyze the effects of external factors (facilitation conditions, self-satisfaction, and cost tolerance) on perceived ease of use, perceived usefulness, attitude towards use, and behavioral intention of older adults in Indonesia. This research uses basic business research with causal objectives and quantitative research approaches. This research uses a sample of 200 smartphone user respondents aged 55 years and over who live in Indonesia and have used a smartphone for at least six months. The analysis in this study uses SEM (Structural Equation Modeling) and then testing the Measurement Model and Structural Model using IBM SPSS statistical 24 for Windows software and AMOS 24 for windows software. This study indicates that perceived usefulness has a significant effect on attitude towards use but does not have a significant effect on behavioral intention. Perceived ease of use has no significant effect on attitude towards use, behavioral intention, and perceived usefulness. Attitude towards use has a significant effect on behavioral intention. Facilitating conditions significantly influence perceived ease of use and perceived usefulness but do not have a significant effect on behavioral intention. Self-satisfaction and Cost tolerance have a significant effect on perceived ease of use but have no significant effect on perceived usefulness and behavioral intention.
\end{abstract}

Keywords: Perceived ease of use, Perceived Usefulness, Attitude towards use, Behavioral Intention, SmartphoneTechnology Acceptance.

\section{INTRODUCTION}

Nowadays, one of the technologies with the fastest growth rate is the smartphone. Many people are switching their mobile phone to a smartphone because of the features it offers. In 2019, it was recorded that smartphone users in Indonesia reached about 92 million people compared to the total population of 266,91 million people

(https://databoks.katadata.co.id/).

This number continues to increase in all users' age groups, including those above 50 years old. According to a survey conducted by Pew Research Center, the number of smartphone users increased from $2 \%$ in 2015 to $13 \%$ in 2018 (https://tekno.tempo.co/read/1181645/surveikepemilikan-smartphone-indonesia-peringkatke-24). A smartphone is used for various needs, such as calling, texting/chatting, browsing, playing games, taking pictures, etc.

Besides the ability to fulfill many needs and its features, the usage and acceptance of smartphone technology itself affect many other factors. Acceptance is defined as a positive attitude and behavior towards technology (Chen and Chan 2014). According to Davis (1989), the TAM (Technology Acceptance Model) theory states that acceptance towards new technology significantly is affected by 2 
determinants, namely perceived usefulness and perceived ease of use of the technology. In the UTAUT technology, Venkatesh et al. (2003) state that the critical factor of technology acceptance can be measured through behavioral intention and actual usage of the technology.

\subsection{Research Purposes}

Ma et al. (2016) reveal that perceived usefulness has no significant effect on behavioral intention, perceived ease of use has no significant effect on attitude towards use, and attitude towards use has no significant effect on behavioral intention. However, Roy et al. (2018), Park and Chen (2007), and Pan et al. (2013) argue that perceived usefulness has a significant effect on behavioral intention, perceived ease of use has a significant effect on attitude towards use, and attitude towards use has a significant effect on behavioral intention. The difference of results from these studies has led to a research gap which will be examined further in this study.

This study aims to analyze the relationship between facilitating conditions, self-satisfaction, cost tolerance with perceived ease of use, perceived usefulness, and behavioral intentions, and the relationship between perceived ease of use, perceived usefulness, and behavioral intention with attitude towards use.

\subsection{Hypothesis Development}

Perceived usefulness refers to the level of confidence a person felt that using specific information technology systems will increase their productivity (Davis, 1989). Perceived ease of use and perceived usefulness have a strong positive impact on customers' attitudes, affecting behavioral intention (Roy et al., 2018). According to Roy et al. (2018), customers' attitude appears by the high influence of superior functionality, perceived ease of use, and perceived usefulness.

Therefore, the hypothesis is stated as follows: H1a: Perceived usefulness has a positive ef- fect on attitude towards use of smartphone users in Indonesia.

H1b: Perceived usefulness has a positive effect on behavioral intention of smartphone users in Indonesia.

Perceived ease of use is a level/situation where someone believes that using specific information technology systems does not require any effort (free of effort) (Davis, 1989). This refers to the definition of easiness, which implies free of effort or having less difficulty. Perceived ease of use has a significant effect on attitude through the influence of intrinsic motivation, where the easier the system, the greater the self-efficacy and perceived control a person feels. Perceived ease of use directly affects customers' behavior and indirectly affects perceived usefulness (Davis, 1989).

Therefore, the hypothesis is stated as follows: $\mathrm{H} 2 \mathrm{a}$ : Perceived ease of use has a positive effect on attitude towards use of smartphone users in Indonesia.

$\mathrm{H} 2 \mathrm{~b}$ : Perceived ease of use has a positive effect on behavioral intention of smartphone users in Indonesia.

$\mathrm{H} 2 \mathrm{c}$ : Perceived ease of use has a positive effect on perceived usefulness of smartphone users in Indonesia.

The TAM Theory shows that someone will form a behavioral intention based on their positive attitude. In addition, Carlsson et al. (2006) show that attitude towards use of mobile device/service significantly affects their behavioral intention.

Therefore, the hypothesis is stated as follows: H3: Attitude towards use has a positive effect on behavioral intention of smartphone users in Indonesia.

Facilitating conditions is someone's perception of infrastructures, resources, and techniques in using technology (Venkantesh, 2012). This variable examines how far someone's beliefs that the available technical capabilities can support the use of the systems. UTAUT theory states that facilitating conditions have no direct relationship with behavioral intention but have a direct relationship with actual usage behavior. According to the 
research of Renaud and Biljon (2008), facilitating conditions, perceived usefulness, and ease of learning \& use affect the technology's actual usage. Hence, it is necessary to examine the relationship between facilitating conditions with perceived ease of use, perceived usefulness, and behavioral intention.

Therefore, the hypothesis is stated as follows: $\mathrm{H} 4 \mathrm{a}$ : Facilitating conditions has a positive effect on perceived ease of use of smartphone users inIndonesia.

H4b: Facilitating conditions has a positive effect on perceived usefulness of smartphone users in Indonesia.

H4c: Facilitating conditions has a positive effect on behavioral intention of smartphone users in Indonesia.

Self-satisfaction is a factor that shows the difference between what individuals do and what they aspire to do. (Theodorakis et al., 1996). Self- satisfaction in various studies is often analogous to life satisfaction. According to Chen and Chan (2014), existing constructs, attitude to aging, and life satisfaction have a positive and significant effect on usage behavior but have a negative effect on perceived ease of use.

A positive attitude to aging and high life satisfaction will increase the possibility of using a technology, which later, the usage of the technology will increase the welfare and the selfevaluation of those senior smartphone users. (Xie, 2007).

Therefore, the hypothesis is stated as follows: H5a: Self-satisfaction has a positive effect on perceived ease of use of smartphone users in Indonesia.

H5b: Self-satisfaction has a positive effect on perceived usefulness of smartphone users in Indonesia.

H5c: Self-satisfaction has a positive effect on behavioral intention of smartphone users in Indonesia.

Morgan and Hunt define cost tolerance as the cost tolerated by consumers to use the technology. Several studies consider that socialeconomics issues (employment status, profession, and income) faced by older adults might affect their adoption of technology products and services (Ho dan Kwok, 2003; Bina and
Giaglis,2005). According to Ma et al. (2016), cost tolerance is considered as a direct factor that determines the behavioral intention of those senior smartphone users. Therefore, the hypothesis is stated as follows:

H6a: Cost tolerance has a positive effect on perceived ease of use of smartphone users in Indonesia.

H6b: Cost tolerance has a positive effect onperceivedusefulness of smartphone users inIndonesia.

H6c: Cost tolerance has a positive effect on behavioral intention of smartphone users in Indonesia.

\section{RESEARCH METHODS}

This study is classified as basic business research, aiming to develop a theory or concept of a particular topic. This study is causal research that aims to examine the cause and effect between variables. (Zikmund, 2009:16). Using a quantitative approach, this research aims to test the existing hypothesis, including 7 variables, consisting of 3 exogenous variables: facilitating condition, self-satisfaction, and cost tolerance; and 4 endogenous variables, namely, perceived ease of use, perceived usefulness, attitude towards use, and behavioral intention.

This research was conducted by distributing online questionnaires consisting of several 7 points numerical statements to the number of samples from a population determined using non-probability sampling techniques and using sampling techniques from people who met specific criteria namely purposive sampling (Cozby and Bates, 2012). The target population was smartphone buyers and users in Indonesia, aged 55 years or over, used smartphone for at least six months. The analysis in this study used SEM (Structural Equation Modeling). The Measurement Model and Structural Model were tested using IBM SPSS statistical 24 for Windows software and AMOS 24 for windows software. 


\section{RESULTS AND DISCUSSIONS}

The results of data processing show that all tests meet the goodness of fit index requirements, where CMIN/DF, TLI, CFI meet the good fit requirements, RMSEA is categorized as better close fit and GFI that meets the marginal fit, which is still acceptable.

After fulfilling the goodness of fit index requirements, hypothesis testing is done to the structural model, which leads to the following results:

Table 1. Hypothesis Testing Results

\begin{tabular}{|c|c|c|c|c|}
\hline $\mathbf{H}$ & Path & $\begin{array}{l}\text { Std. } \\
\text { Estimate }\end{array}$ & C.R. & Results \\
\hline H1a & $\mathrm{PU} \rightarrow \mathrm{AT}$ & .664 & 6.731 & supported \\
\hline $\mathrm{H} 1 \mathrm{~b}$ & $\mathrm{PU} \rightarrow \mathrm{BI}$ & -.293 & -.991 & Not supported \\
\hline $\mathrm{H} 2 \mathrm{a}$ & $\mathrm{PEOU} \rightarrow \mathrm{AT}$ & -.009 & -.122 & Not supported \\
\hline $\mathrm{H} 2 \mathrm{~b}$ & $\mathrm{PEOU} \rightarrow \mathrm{BI}$ & -.088 & -.548 & Not supported \\
\hline $\mathrm{H} 2 \mathrm{c}$ & $\mathrm{PEOU} \rightarrow \mathrm{PU}$ & -.181 & -1.633 & Not supported \\
\hline H3 & $\mathrm{AT} \rightarrow \mathrm{BI}$ & .278 & 2.133 & supported \\
\hline $\mathrm{H} 4 \mathrm{a}$ & $\mathrm{FC} \rightarrow \mathrm{PEOU}$ & .143 & 2.373 & Supported \\
\hline $\mathrm{H} 4 \mathrm{~b}$ & $\mathrm{FC} \rightarrow \mathrm{PU}$ & .898 & 7.752 & Supported \\
\hline $\mathrm{H} 4 \mathrm{c}$ & $\mathrm{FC} \rightarrow \mathrm{BI}$ & .029 & .112 & Not supported \\
\hline H5a & $\mathrm{SS} \rightarrow \mathrm{PEOU}$ & .430 & 5.143 & Supported \\
\hline $\mathrm{H} 5 \mathrm{~b}$ & $\mathrm{SS} \rightarrow \mathrm{PU}$ & .149 & 1.593 & Not supported \\
\hline $\mathrm{H} 5 \mathrm{c}$ & $\mathrm{SS} \rightarrow \mathrm{BI}$ & .173 & 1.250 & Not supported \\
\hline H6a & $\mathrm{CT} \rightarrow \mathrm{PEOU}$ & .422 & 5.284 & supported \\
\hline $\mathrm{H} 6 \mathrm{~b}$ & $\mathrm{CT} \rightarrow \mathrm{PU}$ & -.010 & -.112 & Not supported \\
\hline $\mathrm{H} 6 \mathrm{c}$ & $\mathrm{CT} \rightarrow \mathrm{BI}$ & -.183 & -1.500 & Not supported \\
\hline
\end{tabular}

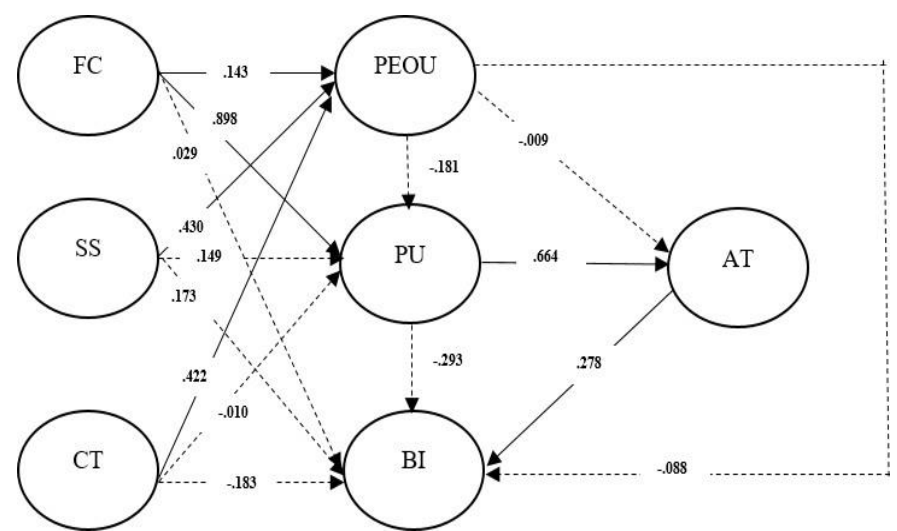

Figure 1. Hypothesis Results

\section{CONCLUSION}

Based on the research results, it is known that behavioral intention has an effect on attitude towards use. Users will use smartphones in the long term and recommend them to their relatives if they like using smartphones. Thus, smartphone companies need to add valuable features that lead to user's positive attitudes towards the smartphone.

To generate those positive attitudes (liking smartphone use and interested in exploring related technologies), smartphone companies need to focus on increasing perception that smartphone is functional (perceived usefulness). Senior smartphone users can feel the usefulness of their smartphones when parties assist them in solving the problems in using smartphones (facilitating conditions). In this case, smartphone companies need to provide various assistance such as relevant features, guides, and training to assist senior users in using the smartphone.

Besides, this study shows that family and relatives play an essential role in using smartphones among seniors. In this study, the majority $(56,5 \%)$ of seniors using a smartphone from family recommendations. Therefore, smartphone companies need to create a good image and positive impressions by helping the users solve their smartphone problem, leading to a good recommendation to their relatives to use the same brand.

This study has several limitations, where the majority of respondents come from big cities in Java islands, so this study can not accurately represent the smartphone usage situation in Indonesia. In addition, various other factors are affecting the variables but were not examined in this study. Future research needs to distribute the questionnaires more evenly throughout the studies to obtain more accurate data. Future researchers need to add various other variables that might directly affect smartphone technology acceptance as a mediator, such as user experience, perceived benefit, and other external factors.

\section{REFERENCES}

Bina, M. \& Giaglis, G. 2005. Exploring early usage patterns of mobile data services. 363- 369.

Carlson, C., Walden, P., \& Bouwman, H. 2006. Adoption of $3 \mathrm{G}+$ services in Finland. International Jour- 
nal of Mobile Communications, 4(4): 369-385.

Chen, K., \& Chan, A. H. S. 2014. Gerontechnology acceptance by elderly Hong Kong Chinese: a senior technology acceptance model (STAM). Journal of Ergonomics, 57(5), 635-652.

Cozby, P. C \& Bates S.C. 2012. Methods in behavioral research. Twelfth ed. McGraw Hills, USA.

Davis, F. D. 1989. Perceived usefulness, Perceived ease of use, and User Acceptance of Information Technology. MIS Quarterly, 13(3): 319.

Ho, S. Y., \& Kwok, S. H. 2003. The Attraction of Personalized Service for Users in Mobile Commerce: An Empirical Study. Journal of ACM SIGecom Exchanges, 3(4): 10-18.

Katadata. 2016. Pengguna Smartphone di Indonesia 2016-2019. Retrieved from https://databoks.katadata.co.id/datapublish/2016/08/ 08/pengguna-smartphone-di-indonesia-2016-2019.

Katadata. 2019. Jumlah Penduduk Indonesia 2019 Mencapai 267 Juta Jiwa. Retrieved from https:// data-

boks.katadata.co.id/datapublish/2019/01/04/jumlahpenduduk-indonesia-20 19-mencapai-267

Ma, Q., Chan, A. H. S., \& Chen, K. 2016. Personal and Other Factors Affecting Acceptance Of Smartphone Technology by Older Chinese Adults. Journal of Applied Ergonomics, 54: 62-71.

Morgan, R. M., \& Hunt, S. D. 1994. The Commitment-Trust Theory of Relationship Marketing. Journal of Marketing, 58(3): 20-38.

Pan D., Chen N., Rau PL.P. 2013. The Acceptance and Adoption of Smartphone Use among Chinese College Students. In: Rau P.L.P. (eds) Cross-Cultural Design. Methods, Practice, and Case Studies. CCD 2013. Lecture Notes in Computer Science, vol 8023. Springer, Berlin, Heidelberg. https://doi.org/10.1007/978-3-642-39143-9_50

Renaud, K., \& Van Biljon, J. (Eds.). 2008. Predicting Technology Acceptance and Adoption by The Elderly. Proceedings of the 2008 Annual Research Conference of the South African Institute of Computer Scientists and Information Technologists on IT Research in Developing Countries Riding the Wave of Technology - SAICSIT '08. 1456684. doi: 10.1145/1456659.1456684

Roy, S.K., Balaji, M.S., Quazi, A., \& Quaddus, M. 2018. Predictors of Customer Acceptance of and Resistance to Smart Technologies in The Retail Sector. Journal of Retailing and Consumer Services, 42(May): 147-160.

Theodorakis, Y., Maliou, P. Papaioannou, A., Beneca, A., \& Filactakidou, A. 1996. The Effect of Personal Goals, Self-Efficacy, and Self Satisfaction on Injury Rehabilitatio. Journal of Sport Rehabilitation, 5(3), 214-223. doi: 10.1123/jsr.5.3.214

Theodorakis, Yannis. 1996. The Influence of Goals, Commitment, Self-Efficacy and Self-satisfaction on Motor Performance. Journal of Applied Sport Psychology, 8(2): 171-182. doi: 10.1080/10413209 608406475
Venkatesh, V., Morris, M.G., Davis, G.B., \& Davis, F.D. 2003. User Acceptance of Information Technology: Toward a Unified View. MIS Quarterly, 27(3): 425-478

Venkatesh, V., Thong, J. Y. L., \& Xu, X. 2012. Consumer Acceptance and Use of Information Technology: Extending the Unified Theory of Acceptance and Use of Technology. MIS Quarterly, 36(1): 157-178.

Xie, B. 2007. Using the Internet for Offline Relationship Formation. Journal of Social Science Computer Review, 25(3): 396-404. doi: $10.1177 / 0894439307297622$

Zikmund, W \& Babin B. 2009. Essentials of Marketing Research. fourth Ed. Cengage Learning. South Western. 